\title{
“GREEK PROJECT" - CLUE TO THE HISTORY OF GEORGIA 50-90-IES OF XVIII CENTURY
}

\author{
Mamuka Natsvaladze, \\ Doctorate; Sokhumi State University; Tbilisi, Georgia \\ DOI: https://doi.org/10.31435/rsglobal_conf/25112020/7247
}

\begin{abstract}
Global international project of the 70-80-s of the XVIII century envisaging a new distribution of Europe based on the areas of the Ottoman Empire is reviewed in the article. This topic acquires a final feature in a conceptual form in the correspondence between Catherine II and the Emperor of Austria and the Holy Roman Empire Josephus II under the name of "Greek Project".

The article is a scientific fragment of a monograph, reviewing the Greek Project in regard of the Caucasus for the first time in historiography.

Initially, Soviet historiography strictly separated itself from the Greek Project, since the objective research of the latter would ensure presenting the Russian Empire as an aggressive state. Afterwards, the research of this project was converted into a narrow political framework and presented as a plan to conquer Crimea.
\end{abstract}

The Greek Project can be unequivocally considered as a key to the history of Georgia of 50-80-ies of the XVIII century. A number of studies have shown that numerous problematic questions remain unanswered until the present day without considering the Greek Project.

Patience and tolerance shown by the King of Kartli - Kakheti Erekle II towards the Russian intrigues cannot be explained without the Greek Project. Georgia acquires qualitatively different and desired form of all time through the implementation of the Greek Project.

The Greek Project is an attempt to create a Christian global political model, a political background that can serve as a precondition for the restoration of a real united Caucasian Home, ensuring a guarantee of irreversible development and security for all royal principalities and khanate in the Caucasus.

This is the reason, the state oriented thinker Erekle II, avoids responding with aggression to the permanent intrigues of Russia. Erekle II tries to get involved in this great political game as a sovereign of a full-fledged political entity.

Such attitude of Erekle is a guarantee of success for the Imperial Court of St. Petersburg. However, Russia chooses a completely different way - confronting Erekle's benevolent alliance with hostile, imperial sentiments. The main message of these sentiments is that a united Caucasus, independent Georgian kingdoms for Russia is considered to be an anti-Russian phenomenon.

This consistent and hostile attitude towards the Caucasus became the reason for the failure of Russian policy - it could neither establish a model of Christian globalization nor neutralize the Ottomans. Therefore, the study and understanding of the referred problem is rather important to determine the directions and priorities of modern political processes.

Keywords: Greek Project; Ottoman Empire; Kingdom of Kartli-Kakheti; Erekle II; Catherine II; Joseph II, Friedrich II, Russian Empire; The Holy Roman Empire of the German Nation.

Introduction. Second half of the XVIII century stands for a landmark in the History of Georgia. The processes of the Russian occupation in Georgia starts from the referred period of time. Soviet historiography aimed to review the period from the ideological viewpoint of the latter. However, ideological conjuncture actually served to separate the ongoing events in the Caucasus from the world historical processes. Therefore, answers to numerous questions, emerged during the study and research of the Georgian History for the second half of XVIII century, are absent or at least lack credibility.

Purpose. The referred period of the History of Georgia has not been studied yet within the context of an event, a seven-year-war, having a worldwide importance. In addition, the plan of that time for the redistribution of Europe - "Greek Project", developed at the Imperial Court of St. Petersburg and Vienna has also been ignored.

Our research topic is characterized by multifaceted forms. Therefore, different research methods are required for the complete analysis of the issue.

Research methods. We rely on the methodological principles of objectivity, historicism, determinism, alternativeness, reconstruction, developed in the theoretical studies by the following 
scientists: Charles-Victor Langlois, Charles Seignobos; Robin George Collingwood [Collingwood 1993]; Marc Léopold Benjamin Bloch [Bloch 1952]; Peter Lambert and Phillipp Schofield [Lambert, Schofield 2004]; Abrams Lynn [Abrams Lynn 2010]; Brundage Anthony [Brundage 2017]; Gregory Ian, Ell Paul [Gregory Ian, Ell Paul 2008]; Hughes-Warrington [Hughes-Warrington 2007]; Iggers George, Wang Qiang Edward [Iggers, Wang 2013]; Akira Iriye [Iriye 2012]; Kaldellis Anthony [Kaldellis Anthony 2014]; Koselleck Reinhart [Koselleck 2004; Koselleck 2002]; Lukacs John [Lukacs John 2000]; Munro Doug, Reid John [Munro Doug, Reid John 2017]; Quigley Carroll [Quigley Carroll 1979]; Raaflaub Kurt [Raaflaub Kurt 2010].

Research results. Since the XV century, policy of various European countries, being reviewed in regards to the Ottoman Empire, was directly related to the ongoing events in Georgia. Accordingly, all issues related to the neutralization of the Ottoman Empire and the redistribution of its territories were extremely important for Georgia.

Our research process conducted for many years, revealed that all problems existing in the History of Georgia of 50-90-ies of XVIII Century are organically bound to the Greek Project. This Russian-Austrian project anticipated the creation of a unified Christian global space alongside with the neutralization of the Ottoman Empire. Based on its geostrategic location, the Caucasus occupies an extremely important place in this global Christian political space.

It is also known that the Russian Empire as a Christian state has been regarded in the consciousness of Georgians as an ally in the fight against the Muslim political spectrum for centuries [Tsintsadze 1960:24-63; Guruli 2008:38-45], used by Russia in its favor for double, sometimes even triple political games. Examples of this are the tragedy of Zegami in 1605 [Jamburia 1998:18-22], the Adventure of Peter I in 1721 [Kacharava 1998:239-242; Chichinadze 1920A:3-12]. Attempt to liquidate Errekle II by means of Totleben and then decrown him from the Kartli-Kakheti throne by Captain Lvov is a continuation of the mentioned political style, followed by a cascade of similar political adventuresassassination of Prince Levan, [Tukhashvili 1983:8; Jambakur-Orbeliani 1914A:14-18; Berdzenishvili 1973A:255-262], then murders of the ambassadors sent to the Emperor of Austria, [Tabaghua 1979:79126; Kalandia 2017:11-14; Peradze 2006:84-89] rise of various adventurers at the royal court of KartliKakheti, [Shvelidze 2012:108-112; Gelashvili 2002:130-138; Guruli 2015:33-35] poisoning future King George [Natsvaladze 01.05.2017:15], concluding the Treaty of Georgievsk [Guruli 2013A:23-33; Paichadze 1983:62-65; Macharadze 2013:109-120; Papashvili 2003:307-310] and then violating the terms of the latter in four years [Guruli 2013B:18-20; Lobzhanidze 1989:235-237] these cascade of intrigues is crowned by the devastation of Tbilisi in 1795 by Agha Makhmad Khan [Potto 1891:1-2; Tsintsadze 1969:170-175; Kikodze 1942:209-221; Shvelidze 2016:52-53].

Even in late 1770s of the XVIII century, it became apparent that the political intrigues of St. Petersburg were of irreversible character. Erekle II aims to neutralize this difficult and at the same time chronic Russian political adventure by constantly seeking the ways of relations with Western European countries [Tamarashvili 1995:616-739; Chichinadze 1895:23-46; Tabaghua 1987:243-255; Chichinadze 1920B:243-255; Doborjginidze 2013:237-246].

That is why the Kingdom of Kartli-Kakheti needs a connection with the Austrian Emperor Joseph II, since it should actively get involved in the implementation of the Greek Project, that serves as a precondition of transferring Georgian Kingdoms and Caucasian political space in a qualitatively different condition.

Contact with the State of Venice is of great importance as well [Chichinadze 1917:8-15], the letters sent by Erekle II, emphasize the fact that Georgia has always defended Christianity faithfully [Tabaghua 1979:78-135; Tamarashvili 1995:557-583]. This is the message, with the sub-text for the Powerful States to recognize Georgian royal principalities as a full-fledged players in the newly started global religious-political processes.

The prism of the Greek Project clearly shows the impulses giving special motivation to Georgian Royal Kingdoms to be actively involved in international processes.

The main target of Russia and Austria is the Ottoman Empire, this is a position shared by Erekle II. In order to find out the reasons of like-mindedness of Erekle II, the negative processes facilitated by the Ottoman Empire in Georgian kingdoms shall be analyzed.

We believe, one important explanation is needed - in regard of understanding and consciousness Erekle is a large-scale politician, he is not locked in the shell of the king of KartliKakheti. Erekle is the ruler guided by the principle of unified Georgian state. Moreover, his vision is 
broad and extends not only to whole Georgian but the scales of unified Caucasus as well. Accordingly, he thinks of the Ottoman Empire within a unified Caucasian prism.

Although the two political areas - the Kingdom of Kartli-Kakheti and the Ottoman Empire are geographically separated; although they do not have a common border, Erekle evaluates the events from a common Caucasian point of view. Accordingly, the fact that two most important trump cards of the united Caucasus - access to the sea [Ninidze 1998:71-77] and the North Caucasus [Japaridze 2018:344-430; Svanidze 2008:235-243] were neutralized by the Ottoman Empire, develops significant systemic difficulties for any political entity in the Caucasus.

The first major issue, forming an everyday and unresolved problem of the Kingdom of KartliKakheti is the Lezghian raid [Orbeliani 2011:29-32; Alimbarashvili 2010-2013:285-297; Berdzenishvili 1973B:377-382; Itonishvili 2005:42-72; Jambakur-Orbeliani 2014B:7-15]. The satellite of the Ottoman Empire, Dagestan and Chechnya, are geopolitical areas constantly oppressing Eastern Georgia. The constant impulsive raids of the mountaineers cause particular damage to the economy of the kingdom, the agriculture is ruined and the only issue to think is a problem of physical survival.

The second problem is the disruption of Georgia's unique social landscape that is a slow action mine [Beradze 1984:55-62; Rekhviashvili 1982:316-325; Kilasonia 1999:262-269]. Purchase of captives, carried out by the nobles of western Georgia in agreement and based on the order of the Ottoman Empire, has a lethal effect on Georgian statehood, since a unique social landscape is the pillar of statehood guaranteeing internal peace of the country [Natsvaladze 19.06.2017:8]. We have achieved an unprecedented event as a result of preserving the referred landscape - Bagrationi royal dynasty is the only one in the world history not being confronted by its own population.

This segment of the Ottoman imperial concept on the one hand aims to shift the management of the Georgian kingdoms to the Byzantine model, when everyone has an equal right to be king/emperor, which is a pretty tempting motivation to encourage internal turmoil and on the other hand, facilitates maximum alienation of the upper classes from the lower classes, which is a major precondition for the country's internal permanent unrest and confrontation of the population with the royal dynasty.

Third and the most important factor - alienation of the North Caucuses, rather hard process for Georgia started with the attempt of the Ottoman Empire [Megrelidze 2012:12-25]. North Caucasus, formerly a part of unified Georgian cultural sphere, alienated through Islamization [Kebuladze, Kekelia 2014:220-225; Anchabadze, Tsintsadze 1966:151-156] and transformed into a puppet of the Ottoman Empire.

These three problems, posed by the Ottoman Empire as both a rapid and a slow-acting mines are clearly aimed at undermining the Georgian state system model.

This is a continuation of the policy pursued by the world empires of all times and formations (Achaemenid Iran, Rome, Byzantium, Ottoman) for centuries against the united Caucasian House.

Therefore, the anti-Ottoman movement, acquiring an orderly, consistent character in the form of the Greek Project, became especially important not only in terms of strengthening the Georgian state, but also in terms of its rise to a new qualitative reality.

This became clear in the 1970s, when Kartli-Kakheti state actually became dominant in the Caucasus, that was considered as a precondition for the restoration of a unified Caucasian political community [Kvitsiani 2017:145-155].

Erekle II pursues a rather diplomatic policy towards Russia with the desire to execute the Greek Project, with the perspective Georgia could have received in case the implementation of the project. Obviously, he is well aware of imperial intentions of the Imperial Court of St. Petersburg, he has daily contacts with the backstage considering the statehood of Georgian royal principalities as an anti-Russian event.

Conclusions. Without the Greek project, it is impossible to explain Erekle's multifaceted diplomatic moves, quite compromising and deliberate relations with the rulers of the Russian Empire and frequent endurance of personal insults.

Such a deliberate policy of Erekle towards Russia originates from state thinking. Erekle never puts his royal ambitions above the interests of the state, he never acts solely based on personal feelings and emotions. It is obvious from his appeasable and deliberate actions, that he is waiting something important for his country.

The Greek Project has to ensure benefits that are the main motivation of King Erekle's patience. The referred benefits for the country make Erekle endure repeated personal insults from Russia. State 
interest is of paramount importance for Erekle. This is the thesis drawing a red line throughout the life of the King of Kartli-Kakheti. From this viewpoint, it is quite interesting what where the benefits expected by Georgian Royal Court and Feudal Society from Russia for such inhuman patience.

This question is answered by the Russian-Austrian Greek project. If implementing the latter:

1. Elimination of external factors hindering the unification of western and eastern Georgia seemed quite real.

2. Most part of the Caucasus would be within the environment of Christians minimizing the geographical area for the Christian community that may be threatened by Muslims.

3. By neutralizing the Ottoman Imperial Syndrome, the North Caucasus would return to the Caucasian cultural environment, part of which, especially Dagestan, became the satellite of the Ottomans. Consequently, the passes from the North Caucasus would become a part of the unified Caucasian political area.

4. By neutralizing the Ottoman Imperial Syndrome, it would be possible to restore the unprecedented unique Georgian social landscape existing in the world being the main pillar of Georgian statehood throughout the Georgian history.

5. In case of neutralizing the Ottoman threat, a unified Caucasian political space would gain distinct economic incentives and opportunities, through transferring the eastern shores of the Black Sea under the influence of the latter since the referred area gave the possibility to develop active trade relations with Western European countries.

6. Christian globalization, a peaceful political environment would create a quite fertile prospect for the restoration of the Silk Road, which would be especially beneficial not only for KartliKakheti and other Georgian kingdoms, but for the whole region as well.

7. According to the Greek Project, as a result of such political, social and cultural impulses, a secure geopolitical environment would be formed around the Caucasus, which gave the whole region a chance to regain its geopolitical function of world importance, to make the dream of Georgian kings of all time come true.

Based on the above-mentioned factors we must explain that despite a number of anti-Georgian actions clearly expressed by the Russian Empire since the 70s of the XVIII century, anti-Russian sentiments in Georgia did not take a shape of systemic resistance. Anti-Russian sentiments acquired a systemic character after the Russian Empire introduced the verdict of abolition Georgian Kingdom to the nobility of Kartli-Kakheti on April 12, 1802 through an unusual political performance [Shvelidze 14.03.2005:8; Natsvaladze 10.10.2016:15; Chichinadze 1920A:7-12].

The referred decision of St. Petersburg Imperial Court was followed by 5 organized antiRussian revolts in Georgia over the next 30 years [Polievktov 1924:201-214; Khomeriki 2012:320352; Polievktov 1927:107-114; Gelashvili 2003:101-132; Dubrovin 1866:336-342], proving that Georgian political society would tolerate neither the loss of statehood nor the Russian Occupation.

\section{REFERENCES}

1. Anchabadze, Tsintsadze 1966 - Anchabadze, Z. Tsintsadze, M. Georgia and the Northern Caucasus in the XII Century and the I Half of the XIII Century. Georgia in the Rustaveli Era: the collected works dedicated to the 800th anniversary of Shota Rustaveli. Tbilisi, 1966. pp. 144-160.

2. Abrams Lynn 2010 - Abrams Lynn. Oral History Theory, London: Routledge, 2010. 224 p.

3. Alimbarashvili 2010-2013 - Alimbarashvili, I. The Time of Lezgin Raids and the Fortification System in Kartli and Kakheti. Ioseb Alimbarashvili. Zurab Papaskiri - 60: "Chronography Means Speaking the Truth / Sokhumi State University. Tbilisi, 2010-2013. pp. 283-299

4. Berdzenishvili 1973 A - Berdzenishvili, N. Death of Levan Batonishvili. Issues of Georgian history 6. Nikoloz Berdzenishvili.Tbilisi 1973. pp 452-474

5. Berdzenishvili 1973 B - Berdzenishvili, N. The Time of Lezgin Raids in the Second Half of the XVIII Century. Issues of the History of Georgia. vol. 6. Nikoloz Berdzenishvili. Tbilisi, 1973. pp. 369-387

6. Bloch 1952 - Bloch M., Apologie pour l'histoire ou métier d'historien. Librairie Armand Colin, Paris, 2 édition, 1952, $112 \mathrm{p}$.

7. Brundage 2017 - Brundage Anthony. Going to the Sources: A Guide to Historical Research and Writing, $6^{\text {th }}$ Edition. Wiley-Blackwell, 2017. 168 p.

8. Beradze 1984 - Beradze, T. Selling and Buying Captives in Feudal Georgia. Tamaz Beradze. History and Geography in Schools. 1984. N1, pp. 53-63

9. Collingwood 1993 - Collingwood R. G., The Idea of History. Rev. ed., edited and with a new introduction by J. van der Dussen, Clarendon Press, Oxford, 1993. 510 p. 
10. Chichinadze 1920 A - Chichinadze Z., How the Emperor Pavle Took Away Georgia from the Georgian King Giorgi. Tbilisi, 1920 p. 20.

11. Chichinadze 1920 B - Chichinadze Z., "Mr. Oliver Wardrope and the Relations of England with Georgia, Address of King Erekle to the Government of England in 1780, Tbilisi, 192016 p

12. Chichinadze 1895 - Chichinadze, Z. Information by European Confessors and Travelers about Georgia: Letters by King Vakhtang to the King of France and King Erekle's Correspondence with Representatives of England, Tbilisi, 1895. p. 55

13. Chichinadze 1917 - Chichinadze Z., Republicans of the times of the Georgian Kings and King Erekle's Letters to the Government of the Republic of Venice, Tbilisi, $191724 \mathrm{p}$

14. Doborjginidze 2013 - N. Doborjginidze, For Reconstruction of the Historical Memory, compilation of works: "Zurab Kiknadze-80", Tbilisi, 2013 pp 234-257

15. Dubrovin 1866 - Dubrovin N., Transcaucasia in the Years 1803-1806, СПб., 1866.

16. Guruli 2008 - Guruli V., Russia having the Common Faith: Myth and Reality, Tbilisi, Universal, 2008. p 82

17. Guruli 2015 - Guruli V. Shady Enterprise of General Gottlob Tottleben in Georgia, My World, Foundation of Study of Strategies and International Relations of Georgia. Tbilisi, 2015, October. pp. 32-39.

18. Guruli 2013 A - Guruli V. Treaty of Georgievsk (1783) Tbilisi: "Universal”, 2013. p. 56

19. Guruli 2013 B - Guruli, V. Treaty of Georgievsk: Under the "Protection" by the Empire: from the Very Beginning the Russian Empire Was Determined Not to Fulfill the Terms of the Agreement, „Istoriani”: a historical-educational journal. Tbilisi, 2013. July, N7(31), pp. 17-22,

20. Gelashvili 2002 - Traveling Through Georgia. Jacob Reineggs; Translation from German, introduction and bibliography by Gia Gelashvili. „Artanuji” publishing, Tbilisi, 2002; p. 333

21. Gelashvili 2003 - Gelashvili, A. The 1812 Rebellion in Kakheti, “Artanuji” publishing, Tbilisi 2003 p. 323.

22. Gregory Ian, Ell Paul 2008 - Gregory Ian N., Ell Paul S. Historical GIS: Technologies, Methodologies, and Scholarship, Cambridge University Press, 2008. 240 p.

23. Hughes-Warrington 2007 - Hughes-Warrington M. Fifty Key Thinkers on History, London: Routledge, 2007, $480 \mathrm{p}$.

24. Iggers, Wang 2013 - Iggers George G., Wang Q. Edward (authors), Mukherjee Supriya (contributor). A Global History of Modern Historiography, Routledge, 2013. 448 p.

25. Iriye 2012 - Iriye A. Global and Transnational History: The Past, Present, and Future, New York: Palgrave Pivot. 2012. 96 p.

26. Itonishvili 2005 - Itonishvili, Vakh. Banditry of Foreigners in Georgia, Georgian National Academy of Science, Institute of History and Ethnology, Tbilisi: "Mematiane", 2005 ("Ena da Kultura" publishing printing house) p. 82 .

27. Jamburia 1998 - Jamburia G. Tragedy at the royal court of Kakheti: Alexander II, King of Kakheti Tragedy of 1605. history, 1998. N2, p.15-24

28. Jambakur-Orbeliani 1914 A - Jambakur-Orbeliani, A. Batonishvili Levan Bagrationi (Son of Erekle II), Letters and materials for the history of Georgia. Alexander Jam.-Orbeliani, Tbilisi 1914. $23 \mathrm{p}$

29. Jambakur-Orbeliani 2014 B - Jambakur-Orbeliani, A. Lezgins Coming out of Dagestan and Other Stories, Al. Jambakur-Orbeliani, patronymic Vakhtang, published by Sargis Kakabadze according to the autograph protected in the Society Spreading Literacy. Tfilisi, 1914, p. 23

30. Japaridze 2018 - Japaridze A., Metropolitan. Jurisdiction of Georgian Church in Northern Caucasus (Dagestan. Alania. Adyge(i)-Circassia. Durdzukia. Northern-Caucasian Svaneti. Ossetia. Chechnya. Albania), the Standing Committee Establishing the Real History of the Patriarchate of Georgia. Tbilisi, 2018. 744 p.

31. Kalandia 2017 - King Erekle in the English and Irish Press, the information was collected, introduction and comments were provided by Giorgi Kalandia 2017332 p

32. Kacharava 1998 - Kacharava D. Military-political connection of Vakhtang with Russia, Essays on the History of Georgian Diplomacy, II, TSU, Tbilisi, 1998, p 237-246

33. Kebuladze, Kekelia 2014 - Kebuladze, K., Kekelia, I. Contours of the External Politics of Georgia in the XI-XII Centuries in the Section of Modern Strategies; Please find: Collected Works. Gori State Educational University Center of History and Archeology. Gori, 2014. N5, pp.218-227

34. Kvitsiani 2017 - Kvitsiani, J. Caucasia from the Ancient Times to the Second Half of the XIX Century: a course of lectures for the students of the Faculty of Humanitarian Sciences, Tbilisi: "Universal" publishing, 2017. pp.143-159

35. Kikodze 1942 - Kikodze, G. Erekle the II, Tbilisi: "Sakhelgami” publishing, 1942. 236 pp. 209-221

36. Kilasonia 1999 - Kilasonia, A. Buying Captives - a Serious Crime and Social Composition of the Criminals in Georgia of the XVI-XVIII Centuries. Historical Studies. Tbilisi, 1999. N2, pp. 258-271

37. Kaldellis Anthony 2014 - Kaldellis Anthony. A New Herodotos. Laonikos Chalkokondyles on the Ottoman Empire, the Fall of Byzantium, and the Emergence of the West, Dumbarton Oaks, 2014. 324 p.

38. Koselleck 2004 - Koselleck Reinhart. Futures Past: On the Semantics of Historical Time, Columbia University Press, 2004. 336 p.

39. Koselleck 2002 - Koselleck R. The Practice of Conceptual History: Timing History, Spacing Concepts, Palo Alto: Stanford University Press, 2002, 384 p.

40. Khomeriki 2012 - Khomeriki M., Abolition of the Kingdom of Imereti, the 1819-1820 Rebellion and the Imeretian Bagrationis, "Universal” publishing, Tbilisi, 2012. $450 \mathrm{p}$ 
41. Langlois, Seignobos 1992 - Charles-Victor Langlois, Charles Seignobos, Introduction aux études historiques. Editions Kimé, Paris, 1992, 284 p

42. Lambert, Schofield 2004 - Lambert P. and Schofield P. Making History: An introduction to the history and practices of a discipline. Routledge, 2004 - 310 p.

43. Lukacs John 2000 - Lukacs John. Student's Guide to the Study of History, ISI Books, 2000. 53 p.

44. Lobzhanidze 1989 - Lobzhanidze, G. A Study from the History of Legal Relations between Russia and Georgia: [The Legal Status of the Treaty of Georgievsk and Making Georgia a Non-sovereign State, Unilateral Violation of the Agreement by Russia] "Gantiadi”. Kutaisi, 1989. N6, pp.232-237

45. Macharadze 2013 - Macharadze, V. Three Treasures of the Treaty of Georgievsk: Scientific-Public Journal. Tbilisi, 2013. March, N1(7), pp. 100-137

46. Megrelidze 2012 - Megrelidze, D. From the History of the Relations between the Northern Caucasus and Georgia. Times of Lezgins' Raids. Tbilisi, 2012. pp. 9-29.

47. Munro Doug, Reid John 2017 - Munro Doug, Reid John G. (eds.). Clio’s Lives: Biographies And Autobiographies Of Historians, Acton: ANU Press, 2017. 330 p.

48. Natsvaladze 01.05.2017 - Natsvaladze M. Was Giorgi the Twelfth Poisoned as per the Order of the Emperor's Royal Court of Russia, "Rezonansi”, May 1, 2017. p 15

49. Natsvaladze 19.06.2017 - Natsvaladze, M. How the Russian Boot Enrooted Georgian Estrangement, "Rezonansi", June 19, 2017. p. 8.

50. Ninidze 1998 - Ninidze D., Georgian Diplomacy of the Second Half of the XV Century, Essays on the History of Georgian Diplomacy, vol. II, Tbilisi 1998, pp. 58-80

51. Orbeliani 2011 - Orbeliani A. Lezgins Entering Georgia from Dagestan and Other Stories, Historical Heritage: Scientific-Popular Journal. Tbilisi, 2011. N4(17), pp. 28-34,

52. Peradze 2006 - Peradze V. From the History of Relations of Erekle the II with Austria, Historical Verticals. Tbilisi, 2006. N1(10), pp. 82-91

53. Paichadze 1983 - Treaty of Georgievsk: 1783 Agreement on Eastern Georgia Entering Under Protection of Russia. the text was prepared for publication, the introduction and comments were provided by Giorgi Paichadze; Tbilisi: "Metsniereba", 1983, p. 150.

54. Papashvili 2003 - Papashvili, M. Treaty of Georgievsk, this is Georgia, author and editor Akaki Bregadze. Tbilisi, 2003. pp. 305-313

55. Potto 1891 - Potto, V. A. Georgia and Its Historical Past: (Russians Entering Tfilisi in 1783 - Agha Mohammad Khan). Translation by P. Karbelashvili [P. Tskhviloeli]. Iveria, 1891.-26 June, N133, pp.1-2

56. Polievktov 1924 - Polievktov M. A. The Archived "Case" about the Rebellionin Imereti, Guria and Megrelia in the years 1817-1820, Historical Bulettin, Bulleten Historique, Publication of the central archive of Georgia. Tbilisi, 1924. vol. II. pp. 199-220

57. Polievktov 1927 - Polievktov M. A. Archive materials for the history of the 1832 plot in Georgia, Georgian archive. Publication of the central archive of Georgia; Head Management of the Scientific Institutions. Tbilisi, 1927. vol. II. pp. 100-123.

58. Quigley Carroll 1979 - Quigley Carroll. The evolution of civilizations. An introduction to historical analysis, Publisher: Liberty Fund Inc.; 2nd edition (August 1, 1979). 428 pages

59. Raaflaub Kurt 2010 - Raaflaub Kurt A. (ed.) Thinking, Recording, and Writing History in the Ancient World, Wiley-Blackwell, 2010. 440 p.

60. Rekhviashvili 1982 - Rekhviashvili, M. Selling and Buying Captives in Western Georgia. Imereti in the XVIII Century: (Essays) Mikheil Rekhviashvili. Tbilisi, 1982. pp. 311-329

61. Shvelidze 2012 - Shvelidze D. General Totleben in Georgia. Pro Georgia. Journal of Kartvelological studies.Center for east europiean studies- oriental institute-university of Warsaw. Warsaw T. 22, 2012. pp 107-117

62. Shvelidze 2016 - Shvelidze, D. The Epoch of Erekle the II, Tbilisi, Bakur Sulakauri publishing, 2016. 64 pp. $52-53$

63. Svanidze 2008 - Svanidze, M. Ottoman Turkey - Iran War of the Years 1578-1590, Georgia and Eastern Caucasia: Starting the Ottoman Turkey - Iran Wars and Georgia Conquest of the Transcaucasian countries by the Ottoman Turks (1578-1579). International Relations in Eastern Georgia during the Ottoman Turkey - Iran Wars and Georgia (XVI century), Institute of Oriental Studies. Tbilisi, 2008. pp. 226-247

64. Tabaghua 1979 - Tabaghua I., Georgia at the International Arena in the Second Half of the XVIII Century, Tbilisi $1979183 \mathrm{p}$

65. Tabaghua 1987 - Tabaghua I., Georgia in the Archives and Book Depositories of Europe, III, 1987

66. Tsintsadze 1960 - Tsintsadze I., Protective Treaty of 1783: Materials for the history of Russian-Georgian relations, Tbilisi: Sabchota Sakartvelo, 1960 p. 304

67. Tsintsadze 1969 - Tsintsadze, I. Agha Mohammad Khan Attacking Georgia (1795). Tbilisi: "Sabchota Sakartvelo" publishing, 1969. P. 277.

68. Tamarashvili 1995 - Tamarashvili, M. Georgian Church from the Dawn to These Days, "Kandeli", Tbilisi $1995799 \mathrm{p}$. 